\title{
Kinetic Study of Resin-Curing on Carbon Fiber/Epoxy Resin Composites by Microwave Irradiation
}

\author{
Daisuke Shimamoto*, Yusuke Imai, Yuji Hotta \\ Advanced Manufacturing Research Institute, National Institute of Advanced Industrial Science and Technology \\ (AIST), Nagoya, Japan \\ Email: ${ }^{\text {d-shimamoto@aist.go.jp }}$
}

Received 14 February 2014; revised 14 March 2014; accepted 31 March 2014

Copyright (C) 2014 by authors and Scientific Research Publishing Inc.

This work is licensed under the Creative Commons Attribution International License (CC BY). http://creativecommons.org/licenses/by/4.0/

(c) (7) Open Access

\begin{abstract}
Microwave processing has great potential for improving composite manufacturing such as reduction of curing time, energy requirements and operational costs. In this paper, the effects of microwave irradiation for resin-curing of carbon fiber/epoxy resin composite that was composed of discontinuous carbon fibers of $130 \mu \mathrm{m}$ or $3 \mathrm{~mm}$ were investigated. The mechanical properties of carbon fiber/epoxy resin composite cured by microwave irradiation for $20 \mathrm{~min}$ at $120^{\circ} \mathrm{C}$ were similar to ones of the sample prepared by conventional oven for $180 \mathrm{~min}$ at $120^{\circ} \mathrm{C}$. Microwavecured carbon fiber/epoxy resin composite had higher glass transition temperature than the one prepared by conventional oven. The relation between curing time and flexural modulus indicated that the curing velocity of microwave-irradiated carbon fiber/epoxy resin composite was 9 times faster than the one prepared by conventional oven. Furthermore, activation energies for resincuring reaction on microwave- and conventional-cured carbon fiber/epoxy resin composite were estimated. The resin-curing reaction in carbon fiber/epoxy resin composite was promoted by microwave irradiation.
\end{abstract}

\section{Keywords}

Activation Energy, Resin-Curing, Microwave Irradiation, Epoxy Resin, Carbon Fiber

\section{Introduction}

Carbon fiber/epoxy resin composites are attracted attention due to the lightweight materials and the superior

"Corresponding author. 
mechanical properties at automobile, airplane and aviation industries fields. Carbon fiber has excellent strength and stuffiness [1]. Thermosetting resin as epoxy is generally adopted as a matrix component of carbon fiber/epoxy resin composite. Epoxy resin is cured by chemical reactions with base resin and curing agent at high temperature. In general, the epoxy resin is cured by outside heating system such as a conventional electric and/or an autoclave oven. It is known that curing process for epoxy resin is necessary for long time [2] [3]. Moreover, energy consumption in the process of epoxy resin curing is required enormously [4]. The intricacy and high energy consumption of manufacturing techniques have restricted wider industrial use of composites. From these reasons, the development of curing methods with rapid processing time and energy saving properties has been expected at many industrial fields [3] [5] [6].

Microwave irradiation generates heating within the material rather than relying on heat transfer through conduction and convection. Thus, it is more appropriate to consider heating by microwave irradiation as conversion of electromagnetic energy to thermal energy rather than heat transfer [7]-[10]. Therefore, as the rapid thermosetting resin-curing system of carbon fiber/epoxy resin composite, microwave processing has recently attracted attention. However, in the application for resin-curing, there are several discussions about whether or not the microwave irradiation affects rapid resin-curing of carbon fiber/epoxy resin composite, energy saving for resin-curing and mechanical properties as compared to conventional oven [11]-[13]. Thus, effects of microwave processing for carbon fiber/epoxy resin composite have not yet been fully exploited.

In present study, we will demonstrate how microwave irradiation for curing of matrix epoxy resin in carbon fiber/epoxy resin composite, which is composed of carbon fibers with different length, has effects. Resin-curing rate and mechanical properties of microwave-irradiated carbon fiber/epoxy resin composite, which was prepared from different fiber length, were investigated. Moreover, we will show the activation energy of epoxy resincuring on carbon fiber/epoxy resin composite prepared from microwave processing and conventional heating methods.

\section{Experimental Procedures}

\subsection{Materials}

All chemicals and materials were used as received without further purification. Epoxy resin (EPICLON-855) and its curing agent (Aromatic amine, JERCUR-ST11) were obtained from DIC Corporation and Mitsubishi Chemical Corporation, respectively. Carbon fibers with the different fiber length (TORAYCA MLD-300; average length $130 \mu \mathrm{m}$, and TORAYCA T010-003; average length $3 \mathrm{~mm}$, diameter $5 \mu \mathrm{m}$ ) were purchased from Toray Industries, Inc.

\subsection{Preparation and Curing of Carbon Fiber/Epoxy Resin Composites}

Carbon fibers were mixed with epoxy resin and curing agent using a hybrid deformation blender (ARE-310; THINKY Inc.) for $2 \mathrm{~min}$ at $2000 \mathrm{rpm}$. The content of carbon fibers was adjusted to be 5 vol.\% for examining the curing properties of resin. After kneading, the pastes prepared from mixing of carbon fibers and resin were cast into a silicon-mold, and the pre-curing of carbon fiber/epoxy resin composite were obtained after keeping 1440 $\min (24 \mathrm{~h})$ at room temperature $\left(27^{\circ} \mathrm{C}\right)$. Next, post-curing of carbon fiber/epoxy resin composite was performed by both microwave irradiation and conventional heating (SA3100; MASUDA CO.) at $80^{\circ} \mathrm{C}, 100^{\circ} \mathrm{C}$ and $120^{\circ} \mathrm{C}$, respectively. The microwave irradiation power was $1.5 \mathrm{~kW}$ on magnetron multimode type $(2.45 \mathrm{GHz}$, MW-Master; MINO CERAMIC CO.).

\subsection{Characterization}

Mechanical properties of the post-cured carbon fiber/epoxy resin composites were investigated by three-point bending test using autograph apparatus (AG-IS; SHIMADZU CO.). The size of specimens for bending test was $10 \times 80 \times 4 \mathrm{~mm}$. The three-point bending tests were performed at the indenter speed of $2 \mathrm{~mm} / \mathrm{min}$. In order to estimate the degree of curing reaction between epoxy resin and curing agent, glass transition temperature $\left(T_{\mathrm{g}}\right)$ was measured at a heating rate of $5^{\circ} \mathrm{C} / \mathrm{min}$ under $\mathrm{N}_{2}$ flow using scanning calorimeter (DSC, DSC8230; RIGAKU CO.).

Energy consumption for resin-curing of carbon fiber/epoxy resin composites prepared by microwave- and conventional-heating was measured by an operating record system (MW-Master; MINO CERAMIC CO.) and a 
unit chamber volume with power meter (TAP-TST8; SANWA SUPPLY CO.), respectively.

\section{Results}

Figure 1 shows that the flexural modulus, flexural strength and specific stiffness of carbon fiber/epoxy resin
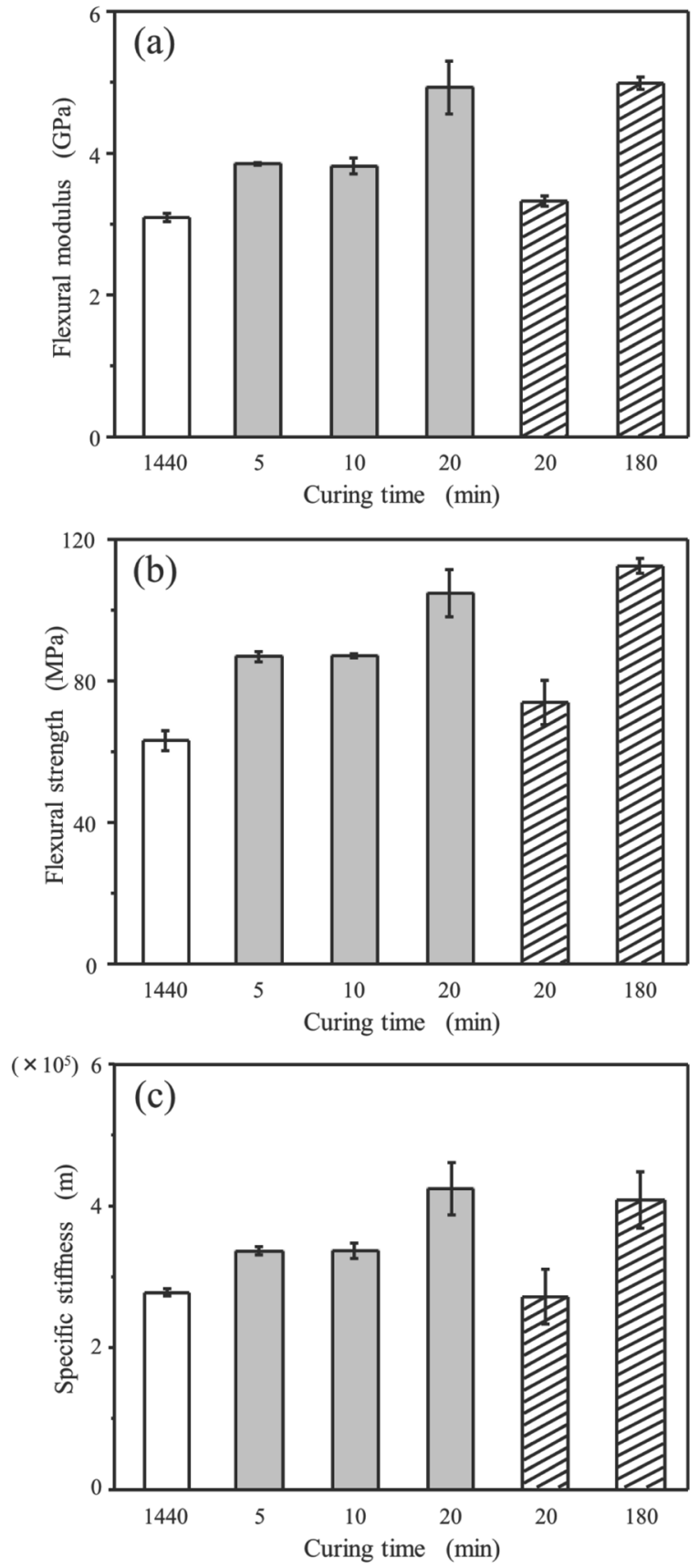

Figure 1. Flexural modulus (a), flexural strength (b) and specific stiffness (c) dependence of curing time on microwave- and conventional-cured carbon fiber/ epoxy resin composites at $120^{\circ} \mathrm{C}$. White, gray and shaded bars show pre-cured carbon fiber/epoxy resin composite for $1440 \mathrm{~min}$ at room temperature, microwave- and conventional-cured carbon fiber/epoxy resin composite, respectively. 
composites with $3 \mathrm{~mm}$ carbon fibers prepared by microwave irradiation and conventional heating at $120^{\circ} \mathrm{C}$, and represents that the mechanical properties of pre-cured carbon fiber/epoxy resin composite which was cured for $1440 \mathrm{~min}$ at room temperature. In the case of the pre-cured carbon fiber/epoxy resin composite, the flexural modulus (Figure 1(a)) was 3.1 GPa. The flexural modulus of carbon fiber/epoxy resin composites cured by microwave and conventional heating processing increased with increasing curing time. In the case of carbon fiber/epoxy resin composites irradiated by microwave for 5, 10 and $20 \mathrm{~min}$, the flexural modulus was 3.9, 3.8, and $4.9 \mathrm{GPa}$, respectively. By microwave irradiation to pre-cured carbon fiber/epoxy resin composite for $20 \mathrm{~min}$, the modulus increased rapidly. The flexural modulus of the microwave-irradiated carbon fiber/epoxy resin composite for 20 min was higher in $60 \%$ than one of the pre-cured carbon fiber/epoxy resin composite. On the other hand, the flexural modulus of carbon fiber/epoxy resin composite prepared by conventional heating for 20 min was $3.3 \mathrm{GPa}$, indicating similar to one of the pre-cured carbon fiber/epoxy resin composite. Thus, the reaction between epoxy resin and curing agent was not accelerated at short time of conventional heating. When the curing time of conventional heating was $180 \mathrm{~min}$, the flexural modulus was $5.0 \mathrm{GPa}$. The value was similar to one of microwave-cured carbon fiber/epoxy resin composite for $20 \mathrm{~min}$ at $120^{\circ} \mathrm{C}$. Flexural strength and specific stiffness (Figures 1(b) and Figures 1(c)) showed the same tendency with flexural modulus (Figure 1(a)), indicating that microwave irradiation could rapidly cure epoxy resin in carbon fiber/epoxy resin composite as compared to conventional heating.

In order to investigate dependence of curing temperature on mechanical properties of cured carbon fiber/epoxy resin composites, microwave- and conventional-cured carbon fiber/epoxy resin composites at 80, 100 and $120^{\circ} \mathrm{C}$ were prepared. Figure 2 shows the flexural modulus, flexural strength and specific stiffness of carbon fiber/epoxy resin composites prepared by microwave irradiation for $20 \mathrm{~min}$ and conventional heating for $180 \mathrm{~min}$ at 80,100 and $120^{\circ} \mathrm{C}$, respectively. The flexural modulus, flexural strength and specific stiffness of carbon fiber/epoxy resin composite cured at room temperature $\left(27^{\circ} \mathrm{C}\right)$ were $3.1 \mathrm{GPa}, 62.1 \mathrm{MPa}$ and $2.8 \times 10^{5} \mathrm{~m}$, respectively. On the other hand, the flexural modulus, flexural strength and specific stiffness of carbon fiber/epoxy resin composites cured by microwave irradiation and conventional heating similarly increased with increasing heating temperature. Furthermore, these mechanical properties of carbon fiber/epoxy resin composite cured by microwave irradiation for $20 \mathrm{~min}$ at $120^{\circ} \mathrm{C}$ were $5.0 \mathrm{GPa}, 108 \mathrm{MPa}$ and $4.4 \times 10^{5} \mathrm{~m}$, respectively, whereas in the case of carbon fiber/epoxy resin composite prepared by conventional heating at $120^{\circ} \mathrm{C}$ for 180 min, the mechanical properties were 5.0 GPa, $110 \mathrm{MPa}$ and $4.1 \times 10^{5} \mathrm{~m}$, respectively. These results prove clear that microwave irradiation for carbon fiber/epoxy resin composites rapidly cures epoxy resin as compared to the one prepared by conventional heating at the same curing temperature.

In addition, energy consumption for resin-curing at $120^{\circ} \mathrm{C}$ by microwave irradiation for 20 min and conventional heating for 180 min was estimated. The energy consumption was calculated from the way of per unit volume of chamber in microwave and conventional oven. The energy consumptions on microwave- and conventional-curing process were 0.1 and $21.1 \mathrm{~kW} \mathrm{~h} / \mathrm{m}^{3}$, respectively. Therefore, it is suggested that microwave processing for rein-curing in carbon fiber/epoxy resin composite has excellent advantage as compared to conventional heating.

Figure 3 shows that the differential scanning calorimeter (DSC) curves of microwave- and conventionalcured carbon fiber/epoxy resin composites at $120^{\circ} \mathrm{C}$. The glass transition temperature $\left(T_{\mathrm{g}}\right)$ was decided from DSC curve by the tangent intersection method [5]. $T_{\mathrm{g}}$ of pre-cured carbon fiber/epoxy resin composite (Figure 3 (a)) was $43^{\circ} \mathrm{C} . T_{\mathrm{g}}$ of carbon fiber/epoxy resin composites prepared by microwave irradiation for 5,10 and 20 min (Figure 3 (d)-(f)) became high slightly with increasing curing time. Particularly, $T_{\mathrm{g}}$ of carbon fiber/epoxy resin composite prepared by microwave irradiation for $20 \mathrm{~min}$ became $2^{\circ} \mathrm{C}$ higher than one of other curing time, indicating that the resin-curing reaction was promoted by increasing microwave irradiation time. On the other hand, $T_{\mathrm{g}}$ of conventional-cured carbon fiber/epoxy resin composite for $20 \mathrm{~min}$ was $43^{\circ} \mathrm{C}$ (Figure 3 (b)), the same as pre-cured carbon fiber/epoxy resin composite. Moreover, the conventional-cured carbon fiber/epoxy resin composite for $180 \mathrm{~min}$ (Figure 3 (c)) showed $44^{\circ} \mathrm{C}$, which is still $2^{\circ} \mathrm{C}$ lower $T_{\mathrm{g}}$ than the microwave-cured carbon fiber/epoxy resin composite for $20 \mathrm{~min}$. The DSC result shows that microwave irradiation promotes curing of epoxy resin in CFRP. This is in agreement with other work by Fang et al. [11].

Figure 4 shows mechanical properties of flexural modulus, flexural strength and specific stiffness for carbon fiber/epoxy resin composites with carbon fibers of $130 \mu \mathrm{m}$ and $3 \mathrm{~mm}$ length. Microwave irradiation was performed for $20 \mathrm{~min}$ at $120^{\circ} \mathrm{C}$. In the case of carbon fiber/epoxy resin composite with $130 \mu \mathrm{m}$ carbon fibers, the mechanical properties prepared by microwave irradiation for $20 \mathrm{~min}$ at $120^{\circ} \mathrm{C}$ have similar with ones by conven- 

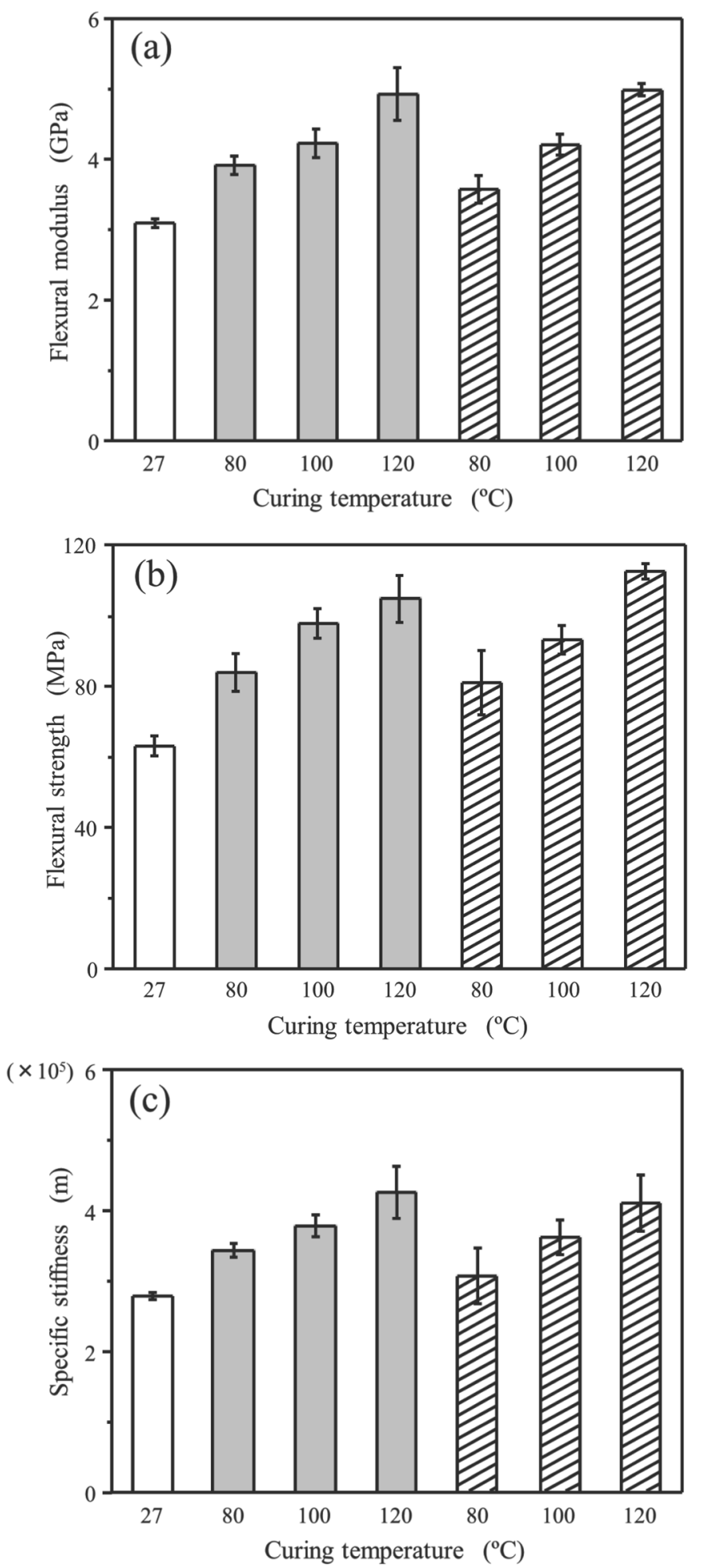

Figure 2. Flexural modulus (a), flexural strength (b) and specific stiffness (c) dependence of curing temperature on microwave- and conventional-cured carbon fiber/epoxy resin composites for $20 \mathrm{~min}$ and $180 \mathrm{~min}$. White, gray and shaded bars show pre-cured carbon fiber/epoxy resin composite at $27^{\circ} \mathrm{C}$, microwave- and conventional-cured carbon fiber/epoxy resin composite, respectively. 


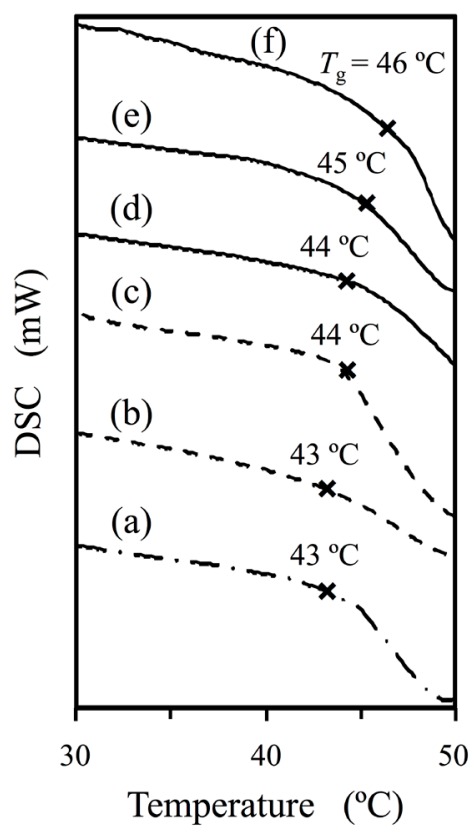

\begin{abstract}
Figure 3. Differential scanning tcalorimeer (DSC) curves of microwave- and conventional-cured carbon fiber/epoxy resin composites at $120^{\circ} \mathrm{C}$, and pre-cured carbon fiber/epoxy resin composite at room temperature for 1440 min (a). Conventional-cured carbon fiber/epoxy resin composites for $20 \mathrm{~min}$ (b), for $180 \mathrm{~min}$ (c), microwave-cured carbon fiber/epoxy resin composites for $5 \mathrm{~min}$ (d), $10 \mathrm{~min}$ (e) and $20 \mathrm{~min}$ (f), respectively.
\end{abstract}

tional heating for $180 \mathrm{~min}$ at $120^{\circ} \mathrm{C}$. The flexural modulus, flexural strength and specific stiffness of microwaveand conventional-cured carbon fiber/epoxy resin composite were 3.9 and $3.7 \mathrm{GPa}, 99$ and $92 \mathrm{MPa}, 3.4 \times 10^{5}$ and $3.3 \times 10^{5} \mathrm{~m}$, respectively. On the other hand, microwave-irradiated carbon fiber/epoxy resin composite composed of $3 \mathrm{~mm}$ carbon fibers had larger mechanical properties than carbon fiber/epoxy resin composites composed of $130 \mu \mathrm{m}$ fibers. Length of carbon fibers in carbon fiber/epoxy resin composite plays a role for improvement of mechanical properties on microwave processing.

Figure 5 shows the duty output power dependence of resin-curing temperature when microwave irradiation to carbon fiber/epoxy resin composites with different length $(130 \mu \mathrm{m}$ or $3 \mathrm{~mm})$ of carbon fibers was performed for 20 min at $80^{\circ} \mathrm{C}, 100^{\circ} \mathrm{C}$ and $120^{\circ} \mathrm{C}$. The duty output power means quantity of microwave for maintaining the setting temperature in oven. In the case of carbon fiber/epoxy resin composite with short carbon fibers of $130 \mu \mathrm{m}$, the duty output power increased as the curing temperature increased. At $80^{\circ} \mathrm{C}, 100^{\circ} \mathrm{C}$ and $120^{\circ} \mathrm{C}$ of curing temperature, the duty output powers were to be $8.7 \%, 10.0 \%$ and $12.6 \%$, respectively. On the other hand, in the case of carbon fiber/epoxy resin composite with long carbon fibers of $3 \mathrm{~mm}$, the duty output power was almost constant to be ca. $6 \%$ at $80^{\circ} \mathrm{C}, 100^{\circ} \mathrm{C}$ and $120^{\circ} \mathrm{C}$ of curing temperature. Furthermore, the power in carbon fiber/epoxy resin composite with $3 \mathrm{~mm}$ carbon fibers was lower than one with $130 \mu \mathrm{m}$ carbon fibers. At $120^{\circ} \mathrm{C}$ of temperature which resin-curing was occurred, the duty output power in the carbon fiber/epoxy resin composite with $3 \mathrm{~mm}$ carbon fibers was half as compared to one with short carbon fibers of $130 \mu \mathrm{m}$, which indicate that carbon fiber/epoxy resin composite composed of long carbon fibers was heated effectively by microwave irradiation with low energy.

\title{
4. Discussions
}

Compared to conventional heating, microwave irradiation leads to a rapid resin-curing and enhancement of mechanical properties of carbon fiber/epoxy resin composite as shown in Figures 1-4. The resin-curing is achieved with very low energy consumption by microwave irradiation. Furthermore, carbon fiber/epoxy resin composite 


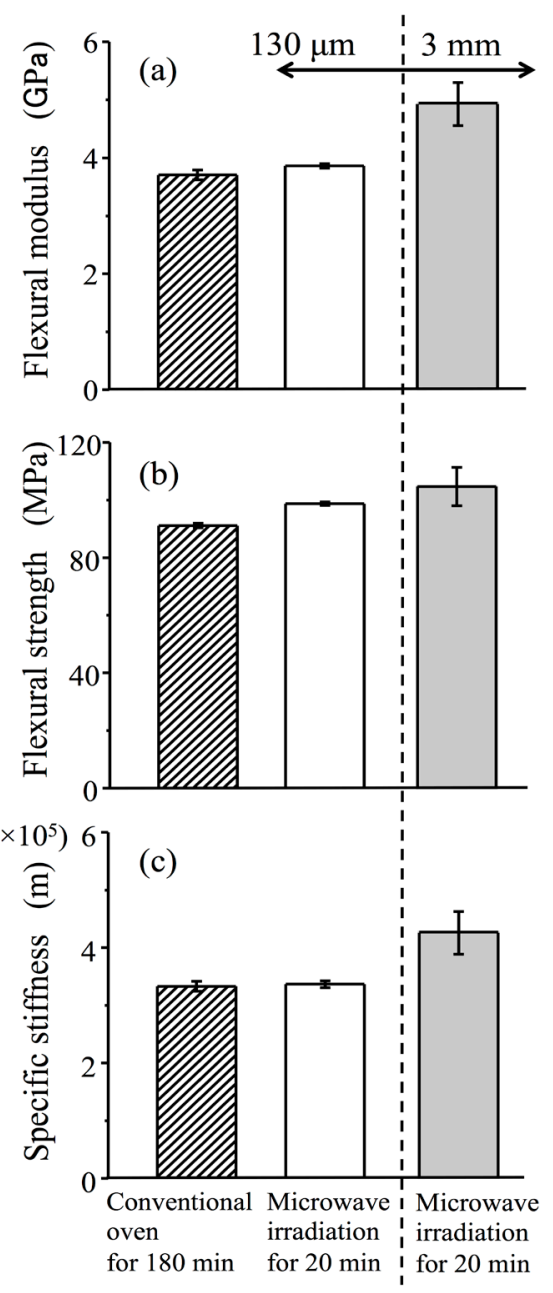

Figure 4. Flexural modulus (a), flexural strength (b) and specific stiffness (c) dependence of carbon fiber length on microwave- and conventional-cured carbon fiber/epoxy resin composites at $120^{\circ} \mathrm{C}$.

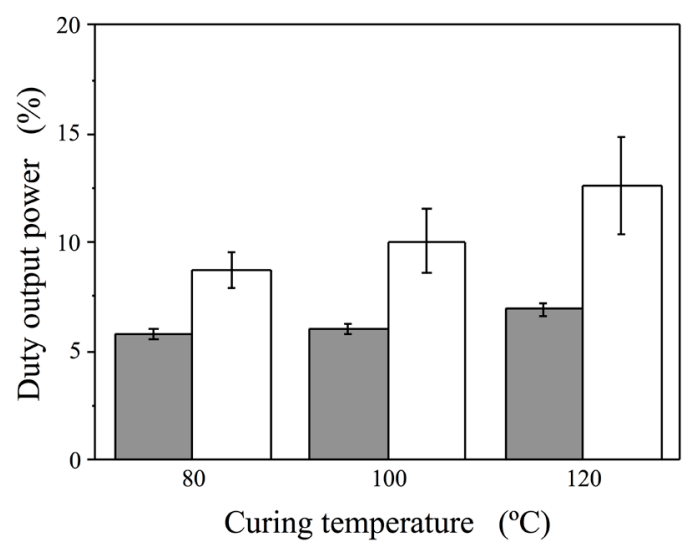

Figure 5. Duty output power of microwave generator, when it is irradiated carbon fiber/epoxy resin composites composed of $130 \mu \mathrm{m}$ (white) and $3 \mathrm{~mm}$ (gray) long carbon fiber for $20 \mathrm{~min}$. 
prepared from long discontinuous carbon fibers is achieved to the setting temperature for resin-curing at the small microwave duty output power of about $6 \%$. On the other hand, the microwave duty output power of carbon fiber/epoxy resin composite with short discontinuous carbon fibers is high and increases with increasing the setting temperature for resin-curing as shown in Figure 5. Thus, it can be concluded that the length of carbon fibers contributes to heating efficiency of microwave to carbon fiber/epoxy resin composite.

It should be of interest to discuss the quantitative difference of the heating efficiency observed between different carbon fiber lengths on microwave irradiation to carbon fiber/epoxy resin composite. In previous reports, microwave processing has been used to perform resin-curing and adhesive of composite materials with very short carbon nanofibers such as carbon nanotube [3] [14] [15], or carbon black [16] [17], as compared to carbon fiber which is utilized to produce carbon fiber/epoxy resin composite.

A heating efficiency can be estimated by the following equation [18],

$$
\eta=1.66 \times 10^{-2} \times M C \Delta T / P
$$

where $P(\mathrm{~kW})$ is the output power, $M(\mathrm{~kg} / \mathrm{min})$ is the treatment amount per minute, $C\left(\mathrm{~J} / \mathrm{kg}^{\circ} \mathrm{C}\right)$ the specific heat, and $T\left({ }^{\circ} \mathrm{C}\right)$ is the temperature. Chang et al. [19] have reported the fabrication of composites at $0.5 \%$ solids loading from epoxy resin/carbon nanotube of $5 \mu \mathrm{m}$ length and $10 \mathrm{~nm}$ diameter by microwave irradiation. They prepared $0.5 \%$ carbon nanotube/epoxy resin composites at $120^{\circ} \mathrm{C}$ by $700 \mathrm{~W}$ of microwave output power. From Equation (1), the heating efficiency $(\eta)$ can be estimated to be $0.3 \times 10^{-3}$. On the other hand, in this study, carbon fibers of $130 \mu \mathrm{m}$ or $3 \mathrm{~mm}$ length, that was much longer than carbon nanotube, were used for the fabrication of carbon fiber/epoxy resin composite. The microwave heating efficiency of carbon fiber/epoxy resin composites composed of $130 \mu \mathrm{m}$ or $3 \mathrm{~mm}$ carbon fibers can be estimated from Figure 5 and Equation (1). Figure 6 shows the relation between curing temperature of $80^{\circ} \mathrm{C}, 100^{\circ} \mathrm{C}$ and $120^{\circ} \mathrm{C}$ and microwave heating efficiency of carbon fiber/epoxy resin composite prepared from $130 \mu \mathrm{m}$ and $3 \mathrm{~mm}$ carbon fibers. The output powers were calculated from duty output power of microwave generator (Figure 5). As shown in Figure 6, $\eta$ of microwave-irradiated carbon fiber/epoxy resin composite prepared from $130 \mu \mathrm{m}$ carbon fibers is almost constant to be $1.6 \times 10^{-3}$ with curing temperature increasing from $80^{\circ} \mathrm{C}$ to $120^{\circ} \mathrm{C}$, whereas $\eta$ of microwave-irradiated carbon fiber/epoxy resin composite prepared from $3 \mathrm{~mm}$ carbon fibers increases with increasing the curing temperature. Particularly, in the case of microwave-irradiated carbon fiber/epoxy resin composite with long carbon fibers of 3 $\mathrm{mm}$ at $120^{\circ} \mathrm{C}, \eta$ was $3.0 \times 10^{-3}$ and was twice compared to the one of microwave-irradiated carbon fiber/epoxy resin composite with short carbon fibers of $130 \mu \mathrm{m}$. This indicates that the length of carbon fiber in carbon fiber/epoxy resin composite obviously contributes to heating efficiency on microwave processing.

Assuming that carbon fiber/epoxy resin composites after conventional heating and microwave irradiation have same structures, their mechanical properties should be similar. As shown in Figure 1, the microwave irradiated carbon fiber/epoxy resin composite for $20 \mathrm{~min}$ at $120^{\circ} \mathrm{C}$ has similar mechanical properties; the flexural

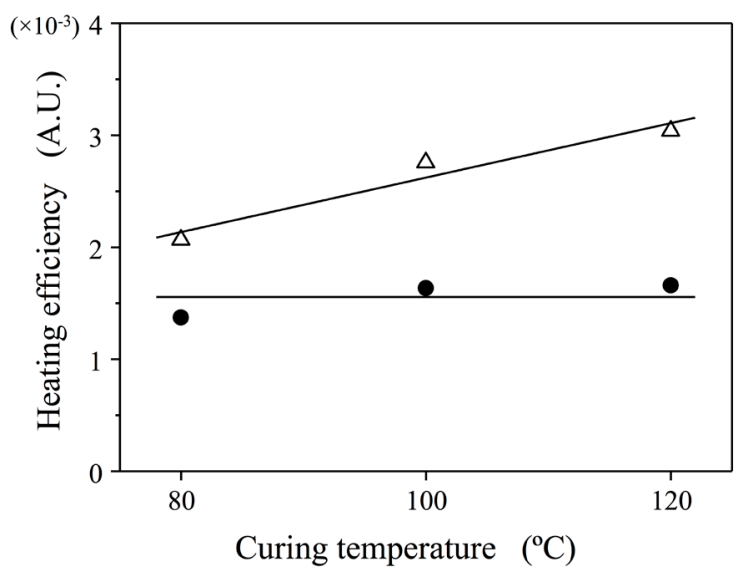

Figure 6. Heating efficiency of microwave-cured carbon fiber/epoxy resin composites composed of $130 \mu \mathrm{m}$ (triangle symbol) and $3 \mathrm{~mm}$ carbon fibers (circle symbol) for 20 min at $80^{\circ} \mathrm{C}, 100^{\circ} \mathrm{C}$ and $120^{\circ} \mathrm{C}$. 
modulus, flexural strength and specific stiffness, to conventional-heated one for $180 \mathrm{~min}$ at $120^{\circ} \mathrm{C}$. Thus, microwave irradiation has an effect of resin-curing in carbon fiber/epoxy resin composite at a short time. The curing time is 9 times faster than conventional heating. It is well known that chemical reaction such as resin-curing can be discussed using Arrhenius equation. Generally, Arrhenius equation is represented as following;

$$
\ln E_{b}=-\frac{E}{R T}+\ln A
$$

where $E_{b}$ is the flexural modulus, $E$ the reaction energy, $R$ is the gas constant, $T$ the reaction temperature, and $A$ is the frequency factor. Figure 7 shows the flexural modulus $\left(E_{b}\right)$ of carbon fiber/epoxy resin composites prepared by microwave irradiation for $20 \mathrm{~min}$ at $120^{\circ} \mathrm{C}$ and conventional heating for $180 \mathrm{~min}$ at $120^{\circ} \mathrm{C}$ as a function of the reaction temperature. The slope $(-E / R)$ of fitting lines is 241 and 242, respectively, which means that the reaction energy of resin-curing by microwave processing is the same as that by conventional heating. That is, in the case of enough temperature and time to cure epoxy resin, the curing reaction of epoxy resin is caused similarly regardless of heating process.

However, as shown in Figures 1-4, the resin-curing rate on microwave processing is faster than one on conventional heating, and the microwave processing leads to an improvement of mechanical properties at shorter time. Generally, chemical reaction such as resin-curing contributes to amount of activation energy as Gibbs free energy. In brief, the rate of curing reaction is fast if activation energy by microwave irradiation is low. The activation energy for curing process on microwave- and conventional-cured carbon fiber/epoxy resin composite can be determined from the mechanical properties data [20]. Curing process kinetic is represented as follows:

$$
E_{b}^{2}-E_{b 0}^{2}=K t+A_{0}
$$

where $E_{b}$ is the flexural modulus at curing time $t$ and $E_{b 0}$ is the initial flexural modulus. $A_{0}$ is constant. When $t=$ 0 then, $E_{b}-E_{\mathrm{b} 0}=A_{0}$. In general, $E_{\mathrm{b}}>>E_{\mathrm{b} 0}$ and then Equation (3) becomes

$$
E_{b}^{2}=K t+A_{0}
$$

In reaction kinetics, $K$ is represented as follows:

$$
K=\left(8 \chi \gamma_{b} V_{M} / N_{A} h\right) \exp \left(-\Delta G^{*} / R T\right)
$$

where $\chi$ is the distance moved of molecule, $\gamma_{b}$ the surface energy, $V_{M}$ the molar volume, $N_{A}$ the Avogadro's number, $h$ the Plank's constant, $R$ the gas constant and $T$ is the curing temperature. Substitution of Equation (4) into Equation (5) reveals the correlation between flexural modulus and curing time:

$$
E_{b}^{2}=\left(8 \chi \gamma_{b} V_{M} / N_{A} h\right) \exp \left(-\Delta G^{*} / R T\right) t+A_{0}
$$

where $\Delta G^{*}$ is the activation energy for curing process. Figure 8 shows the relationship between the square of

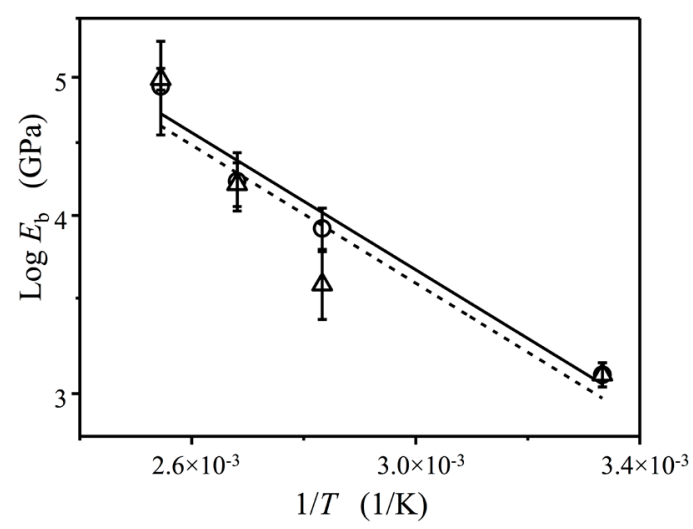

Figure 7. Flexural modulus $\left(E_{b}\right)$ of carbon fiber/epoxy resin composites prepared by microwave irradiation for $20 \mathrm{~min}$ (circle symbol) and conventional heating for $180 \mathrm{~min}$ (triangle symbol) as a function of the reaction temperature. 
flexural modulus and curing time for carbon fiber/epoxy resin composites composed of $3 \mathrm{~mm}$ carbon fibers prepared by microwave and conventional curing at $120^{\circ} \mathrm{C}$. The data was fitted by Equation (7).

$$
Y=a \exp (-b / T) X+c
$$

Table 1 summarizes the fitted equation and the activation energy for curing process $\left(\Delta G^{*}\right)$ in this study. In the case of the carbon fiber/epoxy resin composite prepared by microwave curing, the activation energy was 1.3 $\times 10^{4} \mathrm{~J} / \mathrm{mol}$, whereas the one prepared by conventional curing was $1.7 \times 10^{4} \mathrm{~J} / \mathrm{mol}$. The activation energy for curing process of carbon fiber/epoxy resin composite prepared by conventional curing was about 1.3 times as compared to the one prepared by microwave curing, indicating that the rein-curing by microwave processing is promoted as compared to conventional heating.

\section{Conclusions}

In this study, we investigated the effect of microwave irradiation on epoxy resin-curing in carbon fiber/epoxy resin composite by varying the irradiation time, curing temperature, and discontinuous carbon fiber length. It was shown that the promotion of resin-curing by microwave processing was strongly dependent on carbon fiber length. Carbon fiber/epoxy resin composite composed of longer carbon fibers was heated efficiency by microwave irradiation at low energy.

Moreover, microwave irradiation led to rapid resin-curing as compared to conventional heating. We have demonstrated that the kinetics of resin-curing is explained by Arrhenius plot and activation energy on microwave irradiation and conventional heating. One important consequence of the present study is that choice of processing in view point of activation energy leads to promotion of resin-curing rate. Microwave processing is very suitable for rapid carbon fiber/epoxy resin composite manufacturing.

\section{Acknowledgements}

This study was carried out by the foundation of "Knowledge Hub of Aichi” project in Japan. We give special

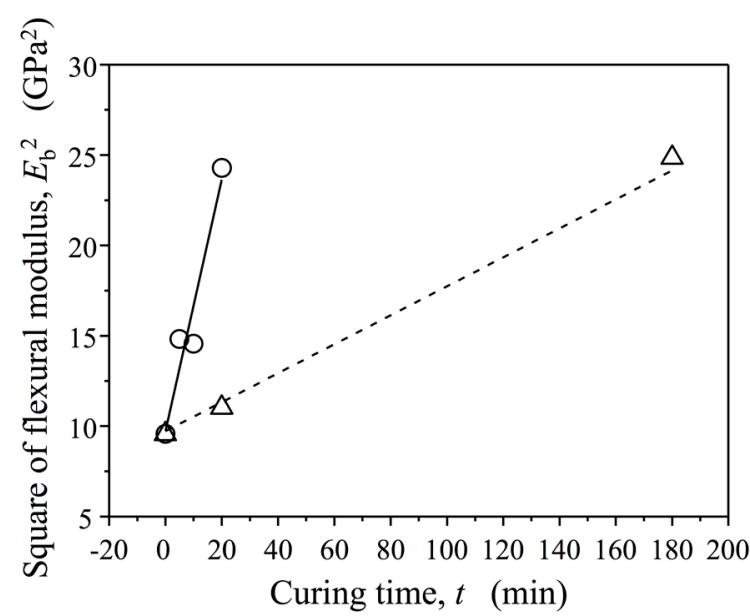

Figure 8. Relationship between the square of flexural modulus and curing time for carbon fiber/epoxy resin composites composed of $3 \mathrm{~mm}$ carbon fibers prepared by microwave (circle symbol) and conventional (triangle symbol) curing at $120^{\circ} \mathrm{C}$.

Table 1. Fitted equation and activation energy for curing process $\left(\Delta G^{*}\right)$ estimated from Figure 8.

\begin{tabular}{ccc}
\hline & Fitted equation & Activation energy for curing process, $\Delta G^{*}(\mathrm{~J} / \mathrm{mol})$ \\
\hline Microwave curing & $\mathrm{Y}=4.1 \times 10 \exp \left(-1.6 \times 10^{3} / 393\right) \mathrm{X}+9.7$ & $1.3 \times 10^{4}$ \\
Conventional curing & $\mathrm{Y}=1.3 \times 10 \exp \left(-2.0 \times 10^{3} / 393\right) \mathrm{X}+9.7$ & $1.7 \times 10^{4}$ \\
\hline
\end{tabular}


thanks to Mrs. Atsuko IJUIN, who made an important contribution to experimental impulsion. Dr. Masaki YASUOKA, AIST, is acknowledged for assisting with the microwave heating.

\section{References}

[1] Huang, X. (2009) Fabrication and Properties of Carbon Fibers. Materials, 2, 2369-2403. http://dx.doi.org/10.3390/ma2042369

[2] Feher, L., Drechsler, K. and Filsinger, J. (2004) Composite Manufacturing by Using a Novel modular 2.45 GHz Microwave Processing System. Proceedings of 36th International SAMPE Technical Conference, San Diego, 15-18 November 2004.

[3] Rangari, V.K., Bhuyan, M.S. and Jeelani, S. (2011) Microwave Curing of CNF/EPON-862 Nanocomposites and Their Thermal and Mechanical Properties. Composites Part A, 42, 849-858.

http://dx.doi.org/10.1016/j.compositesa.2011.03.014

[4] Feher, L. and Thumm, M. (2004) Aerospace CFRP Structure Fabrication with the 2.45 GHz HEPHAISTOS System. Proceedings of MAPEES'04 Symposium, JAPAN, 19-22 March 2004, 129-133.

[5] Yarlagadda, K.D.V.P. and Hsu, S.-H. (2004) Experimental Studies on Comparison of Microwave Curing and Thermal Curing of Epoxy Resin Used for Alternative Mould Materials. Journal of Materials Processing Technology, 155-156, 1532-1538. http://dx.doi.org/10.1016/j.jmatprotec.2004.04.248

[6] Witik, R.A., Gaille, F., Teuscher, R., Ringwald, H., Michaud, V. and Månson, J.E. (2012) Economic and Environmental Assessment of Alternative Production Methods for Composite Aircraft Components. Journal of Cleaner Production, 29-30, 91-102. http://dx.doi.org/10.1016/j.jclepro.2012.02.028

[7] Thostenson, E.T. and Chou, T.-W. (1999) Microwave Processing: Fundamentals and Applications. Composites Part A, 30, 1055-1071. http://dx.doi.org/10.1016/S1359-835X(99)00020-2

[8] Paton, K.R. and Windle, A.H. (2008) Efficient Microwave Energy Absorption by Carbon Nanotubes. Carbon, 46, 1935-1941. http://dx.doi.org/10.1016/j.carbon.2008.08.001

[9] Papargyris, D.A., Day, R.J., Nesbitt, A. and Bakavos, D. (2008) Comparison of The Mechanical and Physical Properties of a Carbon Fiber Epoxy Composite Manufactured by Resin Transfer Moulding Using Conventional and Microwave Heating. Composites Science Technology, 68, 1854-1861. http://dx.doi.org/10.1016/j.compscitech.2008.01.010

[10] Menéndez, J.A., Arenillas, A., Fidalgo, B., Fernández, Y., Zubizarreta, L., Calvo, E.G. and Bermúdez, J.M. (2010) Microwave Heating Processes Involving Carbon Materials. Fuel Processing Technology, 91, 1-8. http://dx.doi.org/10.1016/j.fuproc.2009.08.021

[11] Fang, X. and Scola, D.A. (1999) Investigation of Microwave Energy to Cure Carbon Fiber Reinforced Phenylethynyl-Terminated Polyimide Composites, PETI-5/IM7. Journal of Polymer Science Part A, 37, 4616-4628. http://dx.doi.org/10.1002/(sici)1099-0518(19991215)37:24<4616::aid-pola20>3.0.co;2-w

[12] Nightingale, C. and Day, R.J. (2002) Flexural and Interlaminar Shear Strength Properties of Carbon Fiber/Epoxy Composites Cured Thermally and with Microwave Radiation. Composites Part A, 33, 1021-1030. http://dx.doi.org/10.1016/S1359-835X(02)00031-3

[13] Balzer, B.B. and McNabb, J. (2008) Significant Effect of Microwave Curing on Tensile Strength of Carbon Fiber Composites. Journal of Industrial Technology, 24, 2-9.

[14] Rangari, V.K., Bhuyan, M.S. and Jeelani, S. (2010) Microwave Processing and Characterization of EPON 862/CNT Nanocomposites. Materials Science and Engineering B, 168, 117-121. http://dx.doi.org/10.1016/j.mseb.2010.01.013

[15] Wu, T., Pan, Y., Liu, E. and Li, L. (2012) Carbon Nanotube/Polypropylene Composite Particles for Microwave Welding. Journal of Applied Polymer Science, 126, E283-E289. http://dx.doi.org/10.1002/app.36832

[16] Bouazizi, A. and Gourdenne, A. (1988) Interaction between Carbon Black-Epoxy resin Composites and Continuous Microwaves-I. Electrical Power Dependence of the Rate of Crosslinking of the Epoxy Matrix. European Polymer Journal, 24, 889-893. http://dx.doi.org/10.1016/0014-3057(88)90164-4

[17] Kim, B.G. and Lee, D.G. (2010) Nanometer-Scale Surface Modification of Epoxy with Carbon Black and Electromagnetic Waves. Nanotechnology, 21, 185305. http://dx.doi.org/10.1088/0957-4484/21/18/185305

[18] Toishi, T. and Goto, Y. (2004) Method for Calculating Microwave Power. In: Koshijima, T., Shibata, T., Toishi, T., Norimoto, M. and Yamada, S., Eds., Microwave Heating Technology, NTS, Tokyo, 17-26.

[19] Chag, J., Liang, G., Gu, A., Cai, S. and Yuan, L. (2012) The Production of Carbon Nanotube/Epoxy Composites with a Very High Dielectric Constant and Low Dielectric Loss by Microwave Curing. Carbon, 50, 689-698. http://dx.doi.org/10.1016/j.carbon.2011.09.029

[20] Sato, K., Hotta, Y., Yilmaz, Y. and Watari, K. (2009) Fabrication of Green and Sintered Bodies Prepared by Centrifu- 
D. Shimamoto et al.

gal Compaction Process Using Wet-Jet Milled Slurries. Journal of the European Ceramic Society, 29, 1326-1329. http://dx.doi.org/10.1016/j.jeurceramsoc.2008.08.026 